\title{
The challenge of school-led Teacher Education for those working within traditional Teacher Education partnerships: a case of Roman Riding
}

\section{Dr d'Reen Struthers}

(2016 - Final submission for publication in P. Blessinger \& B. Cozza (Eds.), (2017) University Partnerships in Higher Education (Vol. 5): Emerald Group Publishing.

The impact of political change in England between 2010 and 2016, has been particularly evident in the way the neo-liberal agenda has shaped legislation on Initial Teacher Education (ITE). This chapter will explore the way in which the teaching profession in England has seen tensions mounting between those who see teaching as merely a technical 'craft', something that requires a scant 'training' programme, and those who frame the education of teachers as a more holistic activity and one that should take account of the pedagogies of adult learning, being a journey of critical reflection and lifelong learning. Drawing on evidence from recently published research studies and a small scale research project with members of APTE (Association for Partnership in Teacher Education) in England, six dimensions of the current school-university partnership culture are identified and analysed. The findings show how ITE providers now find themselves juggling involvement in a variety of routes into teaching - like the roman rider straddling various horses.

Over the past 30 years, the whole notion of 'partnership' in English ITE has come under scrutiny, with an increase in routes and qualifications into teaching being driven by the growing government interventions in education, (Alexander, Craft, \& Lynch, 1984; Beauchamp, Clarke, Hulme, \& Kennedy, 2015; Feiman-Nemser, 2001; J Furlong, Barton, Miles, Whiting, \& Whitty, 2000; Whitty, 2014; Wilkin, 1994). Beck (1999) referred to the noticeable 'takeover' (p.223) by neo-liberal governments to ensure free markets and more 
centralised control, while Cochran-Smith talked of the 'policy problem' (2005, p. 3). Still others point to the shift towards a more 'practice-based' focus (Beauchamp, Clarke, Hulme, \& Murray, 2013; Mattsson, Eilertsen, \& Rorrison, 2012; Zeichner, 2013), across most western countries. Neo-liberal governments working with the ideologies of managerialism, accountability and with positivistic measured outputs of pupil achievement, refer to good rankings in the PISA (Programme for International Student Assessment) and OCED (Organisation for Economic Co-operation and Development) tables as their yardstick.

To contextualise English ITE, a brief review of historical antecedents will reveal the way partnership has been variously framed and reframed by consecutive governments since 1984into the current troubled landscape. How do those working in ITE experience these changes? A critique of how those working in ITE experience these changes, will signal the potential challenges to school-university partnerships and the teaching profession.

We begin with a summary of ITE provision in England from 2007-2015.

Table 1: Statistical summary of teacher education provision in England 2007- 2015

\section{TABLE 1 INSERT HERE}

Table 1 depicts the shift in under ten years from the university sector managing $85 \%$ of ITE provision to only managing $32 \%$ by $2015 / 16$. What has brought about this monumental change to ITE in England? What has been the impact for providers - both old and new?

ITE in England has always been built on relationships between Higher Education Institutions (HEIs) and schools. This relationship has been determined by various external factors, with a subsequent impact on ITE provision (Brown, Rowley, \& Smith, 2016; John Furlong, 2013). What were the antecedents for this first set of figures from 2007/08? 
Since 1984 ITE has been increasingly been in the hands of central government as critiqued by Furlong et al., (2000). Of significance to ITE, was the introduction of Circular 9/92 (secondary) and Circular 14/93 (primary) under the Conservative Thatcher Government, who stipulated 'joint responsibility for the planning and management of courses and the selection, training and assessment of students' (DfE, 1992, para 14). They also suggested that schools were ' best placed to help student teachers develop and apply practical teaching skills' (DfE, 1993a, p. 3).

Since the mid-1980s successive English governments have introduced legislation that has begun to stipulate the nature and shape of these partnerships (DES, 1983, 1984; DfE, 1992, 1993, 1993a). A form of inspection was also introduced for all schools and ITE providers by Ofsted (Office for Standards in Education). McNamara (1992, p.274) suggests this was a shift to a model of accountability, making professional activities more accessible to public scrutiny and 'payment by results', a more acceptable proposition. Some commentators (Ball, 1994; Day, 2003; Mahony \& Hextall, 2000), go further to suggest that policy directives represented a new positioning by the government; to stipulate the kind of knowledge necessary for the teaching profession.

By 2000 in the United Kingdom three emerging models of partnership were evident: complimentary, collaborative, and university-led (J Furlong et al., 2000). Within the complimentary model the school and the university had mutually exclusive roles, with very limited integration of effort. Each of the models offered a different epistemological and pedagogical perspective. In the collaborative model of partnership, schools and universities were co-partners. As seen in the Oxford Internship Scheme, students used what they learnt in one setting as the lens through which to view what was learned in another. However, the complementary and HEI-led partnerships were more widespread across England. All models 
valued professional practice in schools, and involved teachers in recruitment, mentoring and assessment; aiming to achieve mutual respect and trust between schools and universities (Furlong et al., 2000).

Thus prior to 2010, the dominant model was an HEI-led partnership where the universities maintained responsibility for control over the content of the programmes and the quality of the school experience, while at the same time, mentors in schools were valued and fully supported through a variety of professional development and career opportunities (Edwards \& Mutton, 2007).

Partnerships between universities and schools are therefore essential in setting up access to these different forms of professional knowledge; providing the opportunities through which these different perspectives may be brought into dialogue with each other (Furlong, et al., 2008, p. 309)

The new Labour government (1997-2010) introduced its own National Curriculum (NC) and continued to use inspectors to monitor partnership arrangements, and compliance to prepare teachers to teach the NC (Campbell \& Husbands, 2000; Evans, Holland, Wolstenholme, Willis, \& Hawksley, 2006). Significantly, schools were not inspected for these areas.

Thus, prior to the next governmental reforms in 2010 with the Conservative-Liberal Coalition, policy makers of various persuasions had already begun to move towards schools playing a greater role in ITE. McNamara \& Murray (2013) suggest that this explicit focus on 'the practical' had also begun to undermine some aspects of the sector's commitment to a research-informed ITE. Therefore, the consequences of the frequently changing legislative frameworks of accountability, inspection regimes and surveillance meant that relationships of necessity needed to be framed in terms of compliance, rather than pedagogical principles. 
As Table 1 shows, prior to 2010, only a small number of schools were prepared to become involved with these alternative routes into teaching. For teachers already in the teaching profession, these changes had an immediate impact on their roles and responsibilities. Edwards and Mutton (2007) noted that:

...the willingness of schools to accept HEI-led partnerships which were largely bureaucratic can be explained by a reluctance to disrupt their historically formed and sometimes precariously sustained social practices aimed at promoting pupil achievement. That is, working in a bureaucratic way did not require schools to rethink their basic focus on pupils. Their reluctance to disrupt school systems was often reflected in the ways that HEI negotiated the new arrangements with them (ibid p. 505).

In 2010 this policy outlined two directives. First, there was to be a rapid expansion of the Academies programme and a freeing up of the school governance system from local control and accountability. Second, the political aspiration was to overhaul teacher training and shift control away from universities into schools. The government did this by developing "a national network of Teaching Schools, on the model of teaching hospitals, to lead the training and professional development of teachers and head teachers. (DfE, 2010).

The new designation of a 'Teaching School' was to encapsulate this thinking with one of their 'big six' priorities being to play a greater role in the training of new entrants to the profession. Additionally, new route into teaching entitled "Schools Direct" was simultaneously proposed to replace the former employment-based route previously provided by EBITTs and enable SCITTs and Teaching School Alliances to have their own pathway. By December 2010 schools began to bid for the 500 places allocated to School Direct for 2012/13; at the same time, universities were informed of their reduced trainee allocations. 
Implemented so quickly and directly into the sector, Teaching Schools and this new School Direct route, had serious repercussions for all in providers of ITE (Struthers, 2013). Teaching Schools were expected to claim a major share of these allocations. Thus Teaching Schools were not just about shifting control away from other agencies but about the education system becoming in essence 'school-led' from within (Hargreaves, 2011). The idea was that School Alliances would form around each Teaching School as a hub. These hubs might vary from alliance to alliance, as determined by this market-driven model (Husbands, 2015).

For former ITE providers, this meant that new relationships had to be brokered as the balance of power changed. It was intended that schools would, from the outset, be able to recruit their own trainees, negotiate terms and conditions of placements, teacher training programme involvement and the like (Jackson, 2013). In reality however, with little experience of recruiting initial trainees, or having a grounded knowledge of what might be involved in a full ITE programme, schools were asking for help from their former partner universities, placing teacher educators in 'messy' territory. While before 2010, partnerships with schools had not generally been based on financial incentives but on professional relationships and commitments to the profession, now, partnership deals were being 'brokered', with both schools and universities considering the cost of their staff involvement.

The shift in provision is also marked by an increased number of 'routes into teaching'; from four in 2007, to now over 20 variations, which encapsulate the marketization of ITE. There is choice now about how, where and when trainees study and more opportunities to match individual need and prior experiences to the chosen pattern of training.

There are worrying patterns too emerging in some school-based programmes where work-placed learning is central, as with the salaried routes for School Direct and Teach First, sometimes referred to as 'apprenticeship models'. Some anecdotal evidence suggests:

- erosion in the recognition of the status of trainees as learners (ATL, 2013) 
- erosion of time and space allocated to learning (ATL, 2014, p. 10)

- the provision of only limited workplace learning opportunities (ibid p. 11)

- tendencies for the replication of practice observed in particular schools (McNamara et al., 2014)

It seems the considerations of adult learning have given way to the demands of the school workplace, in these preferential 'apprenticeship' models.

In reality from 2010, the government stepped away from fully supporting the former quota system, leaving a 'supply and demand' model to ensure that schools could bid for numbers of new teachers as needed. This has left subject departments in universities vulnerable to lower numbers, or in some instances with no allocation. One Professor at Oxford University noted in a blog that, "the previous emphasis on ensuring the quality of recruits has now been replaced by an emphasis on speed - if you don't fill your allocation quickly, the numbers will go elsewhere to school-led providers" (Mentor, 2016).

Thus far I have populated the teacher training partnership landscape in England with the dominating political ideologies that have driven these changes to date; the metrics about actual providers and details of the routes on offer for those wishing to enter the teaching profession. Together, they explain why the review into ITE commissioned by the Coalition government in 2014 led by Andrew Carter, concluded that the system had become 'complex' and information about it 'confusing' (Carter, 2015).

\section{Troubled perspectives on the consequences of change}

Deconstructing the dynamic consequences encountered as a result of these centralist policies is essential to understanding how, in the light of these changes, new directions can be forged - the mark of a resilient professional learning community. As the balance of power between 
universities and schools has been altering, various fields and layers of disturbance have been experienced by the personnel involved. While sometimes 'disturbance' can be a positive and innovative occurrence, in this instance, the impact of these policy directives is being presented as 'disturbances', or 'troubled perspectives'.

To illuminate further the consequences and impact of these changes, evidence will be drawn from recently published research studies along with a small scale research project conducted by the author consisting of qualitative data from an online survey and telephone interviews with APTE colleagues from across the spectrum of provision in England (Struthers, 2016). These 'voices' from a sample of colleagues from across the ITE landscape have been analysed in view of six interconnected perspectives or themes. In this way the author's research offers further 'trustworthiness' (Lincoln \& Guba, 1985; Lyons \& LaBoskey, 2002) to the assertions being made by previous research. The perspectives arising, are all, in their own way, symbiotically connected.

\section{FIGURE 1 INSERT HERE}

Figure 1 represents the elements of new partnership identified, and offers the reader an opportunity to grasp the complexity of the potential 'layers' of disturbance. What appears to be a balanced and symmetrical diagram, can easily be disrupted by one aspect becoming dominant. I have placed "Views about what is involved in learning to teach: programme design and content and becoming a professional" in the central hexagon, as the values and beliefs one holds about pedagogy, learning and teaching and indeed what it is to be a professional, all contribute to the rationales and justifications given to decisions in the other 
hexagons. The concept of each element will now be critiqued to show the implications for personnel involved.

\section{Professional knowledge and learning of teachers in England: underlying beliefs}

Others have discussed the challenge of the theory-practice binary that encapsulates school university partnerships (Allen \& Wright, 2014; Menter, Hulme, Elliott, \& Lewin, 2010; Thomson, 2000; Zeichner \& Bier, 2013). There is the potential for the discourse about teaching and/or learning to be framed differently between the school and the university as well as within each constituency. As power and control shifts, the once dominant discourse from the university is usurped by that of the school or as McDonald et al., (2013) suggests 'a turn away from a predominant focus on specifying the necessary knowledge for teaching toward specifying teaching practices that entail knowledge and doing' (p. 378). Since an education minister declared that 'teaching is a craft and is best learnt as an apprentice' (Gove, 2010), the 'turn to practice' threatens teaching being seen as a 'profession'.

Needless to say, there have been some who have simplified teacher knowledge. Brown et al., (2016) suggest that research is being "crafted as evidence, to be used in straightforward ways to support narrowly defined outcomes rather than progressing critical or analytical ideas of what it means to educate" (p.8). This in turn contributes to the nature of the learning experience that the trainees have, especially when there is less time to critically engage with literature and consider the principles that might apply to different contexts. Their evidence suggested that school-based tutors accepted time was limited. They were more interested in "papers which are shortish, they can get their heads around ... get to the crux of the augments people are making, so they can easily be applied to specific elements" (ibid p.23). 
The introduction of School Direct is having an impact on current models of researchinformed ITE in many universities too, as enacted by the tensions when pedagogical principles are maintained. One university tutor explained:

We lost a major teaching school alliance last year who wanted more of that training and I use 'training' on purpose. And they wanted to do more of that. And so they've gone to another provider and we held firm on that (Brown et al., 2016, p. 21).

Here the domino effect is referenced. As the understanding between the partners was different, a new relationship formed. However, the nuances of this 'difference' in values and beliefs is more pernicious when for financial reasons, some teacher educators have reported finding themselves having to broker uncomfortable compromises. Brown et al., (ibid) reported:

One teacher educator explained how one partnership school refused for a student to do a subject enhancement course despite not having a degree in their chosen specialist subject area. Although the teacher educator felt this was something she 'absolutely could not accept', the pressure was being put on her 'because the school are saying 'we'll go somewhere else' but university management said 'we need the numbers, you can't let them go somewhere else.' (p.19).

From my own research, the Head of Teacher Education at a University commented in a telephone interview: "Financially, it's really crucial for us to maintain $[\mathrm{X}]$ partnership. So therefore there's got to be some kind of flexibility. There's that kind of conflict, ... but there's that balance to try and maintain" (Struthers, 2016). 
Still further, the ownership over programme design has also been at stake, as schools feel able to take control of the teacher 'training' programmes from the position of having the financial levers. One University partnership manager I interviewed stated:

.... in terms of School Direct, we do offer the opportunity for schools to buy into elements of teaching on our course. We can devolve some elements of teaching, but for the primary [course] for example, the line in the sand is, we will not devolve the masters element, nor will we devolve the sort of subject specialism element to schools (Struthers, 2016).

This example of resistance, has not been so explicitly echoed by other university teacher educators interviewed, which further confirms the 'relational' significance of how the university provider is viewed by schools. In support of this approach one School Alliance Head Teacher referred to the "quality of the graduates and the clear marketing and recruitment process offered, in contrast to others who were trying to offer a bit of everything" (ibid p.5). A different view is expressed from one SCITT respondent to the on-line survey (ibid), demonstrating the plethora of bespoke programmes on offer:

As a SCITT we have always had an equal 'power' sharing partnership. Our arrangements with the university are limited to their approving the modules for PGCE which we have designed, holding exam boards and moderating the scripts we have marked (Struthers, 2016).

\section{Brokering a supportive adult learning environment}

For many new school-led providers, considering both the resources and the knowledge necessary to support trainee teachers as adult learners, is a new perspective. Although their university partner may have stipulated support structures and expectations for placing 
students in former partnership agreements, many schools have not accounted for the nature of 'on the job' learning. One teacher educator reported: "Because those on the salaried school direct route has such limited university input, schools put them on a $90 \%$ timetable from day one, seeing them almost as Newly Qualified Teachers" (Brown et al., 2016, p. 18).

Further instances of similar narratives were to be found amongst my research data. Because the university provider is deemed responsible in terms of overall quality assurance at the time of an Ofsted inspection, a tighter application process is necessary.

When we first started with School Direct, the schools wanted to do everything. It was really time consuming. They wanted teachers whom they thought would fit into their school, but we had doubts about whether their skill set and circumstances would support the challenge of the programme. Mopping up the pieces was very time consuming too. This year we have changed things, including the partnership agreement, so our time is more protected (Struthers, 2016).

Other university tutors spoke of the consequence of not seeing the students on a regular basis; students seemingly benefitting from being able to talk to someone outside their employing school. Schools' expectations have often also proved challenging for the trainees. When schools see them as 'teachers' rather than 'beginning or student-teachers' there is little 'wriggle room' for questioning practice. Often, trainees are being expected to have the same outcomes for their pupils in terms of pupil progress and attainment as trained teachers, as schools and academies become more and more data driven. One teacher educator from a SCTT reported:

Since I have moved to this SCITT from a School Direct school that worked with a University, I realise that in my former school we didn't give the trainees time to 
assimilate all that we threw at them. They're were constantly running. In this [SCITT] programme it is still hectic, ... but at least the trainees get to come out and as a group talk about what they are doing. We do ask them about why and what from the course might have helped them (Struthers 2016).

This view suggests evidence of different trainee experiences being offered, depending on the location.

Similar challenges appear with the organisation of alternative teaching placements by schools - something that the university has manged previously. The detail of negotiating expectations with another school (often in a hub of SCITT partnership) was sometimes absent. This meant that the trainee in another school did not get the necessary support. Ellis et al., (2013) refer to the support work that university tutors then found themselves doing as 'relationship maintenance'. This term describes "activities directed at creating and maintaining the networks of relatively fragile personal and institutional relationships between schools, universities, teachers, students and teacher educators that characterise 'partnership' teaching education" (p.271).

\section{Familiar tasks, viewed differently with new identities}

The rise of school-led training has transformed how roles and responsibilities within the partnership are decided. In these partnerships it is the personnel who are most affected with how the categories of 'teacher', 'teacher educator' and 'trainee' are defined. Now the 'teacher educator' inhabits both school and university sites; the boundaries are blurred between 'teacher' and 'teacher educator' and indeed the traditional 'mentor'. This has inevitably impacted the practices of the staff involved and further altered the nature of the trainee experience. 
Several university teacher educators described the way their role involves negotiating across a variety for schools and classrooms, many politically charged with multiple personal agendas. A university teacher educator commented: "my knowledge is much more than just being able to identify good practice. It is about being able to tease out the principles behind practices that work in some contexts and not in others and why. I don't think teachers based in one school for several years have the same expertise" (Struthers 2016).

In keeping with the turn to practice, recruitment to ITE roles has been reported to favour recent school experience. For newer entrants to the role of teacher educator, many are reported as defining their practice in relation to their own experience in schools $-\mathrm{a}$ contextual knowledge - rather than to developing what has been more traditional academic knowledge and capabilities, such as completing Masters qualifications or even a qualification that embraces what it means to teach adults, as expected in higher education settings (Boyd \& Harris, 2010).

Ellis and McNicoll (2015) explore this more fully, concluding that there are tensions between expectations for 'research productivity and quality' and being an excellent practitioner (p.49) when staff are within universities. Boyd and Tibke (2012) consider 'identity dissonance' and the way this can also feature in the practice context for schoolbased teacher educators. The challenges of multiple identities arise from various encounters for example with parents, pupils, colleagues, senior leaders, trainee teachers, governors, university tutors and outside agencies. White et al., (2015) explored what it meant to be a school-based teacher educator. She discovered that while some still define their work around the mentoring role, for which they had previously received some training from the university, seeing the teacher educator-focused responsibilities within this, others have begun to 
recognise that additional responsibilities required them to "develop their own knowledge to do the role" (p.451).

For university teacher educators, from across a range of research studies (Boyd \& Harris, 2010; Brown et al., 2016; Ellis et al., 2013; Ellis \& McNicholl, 2015) there appears a united voice about the way in which the structure of partnership arrangements has become more bureaucratic. One Partnership Manager reported:

I find myself overseeing quality assurance procedures, which often means picking up after an arrangement has failed to offer the correct information for a trainee, or at the last minute due to a crisis in the school, something was abandoned, and that time cannot be 'made up' as easily now, and the content is now missing to be built upon as intended in the next session .... Oh and not to mention the counselling of students to manage the school pressures (Struthers, 2016).

As a consequence of the financial implications for the university, keen to secure research funding, a demarcation of contracts often means some teacher educators are not on academic contracts, while in other institutions, the expectation is that teacher educators should be involved in research inquiry to inform their practice.

\section{Subject knowledge: practical or pedagogical?}

Mitchell \& Lambert (2015) argue that the educational purpose of 'subject knowledge' has been "oversimplified and separated from teachers' concerns with pedagogy, performance and the child's experience" (p. 365). It seems that the policy makers believe school teachers' subject knowledge is sufficient to 'share with trainees'. There is concern that the current, well-established model of the 'good teacher' (Moore, 2004) as a skilled (and accountable) 
classroom technician, fails to support such curriculum work (Connell, 2009; Moore, 2004). Traditionally the subject knowledge base has been held as a strong part of the university input, offering a depth and breadth of research-informed scholarship that can then be pedagogically orientated for teaching in schools. At a school-level the knowledge base is much narrower, informed by regulatory requirements of the National Curriculum, along with informed teaching strategies that adhere to the policy expectations of each particular school context. Another teacher educator pondered his expertise saying "I am not sure it's that I know different things, but I'm able to talk about them I've got a language to talk about them" (Brown et al., 2016).

\section{Inhabiting the market model - recruitment, marketing and competition}

Changes to recruitment and the involvement of schools in the selection and interview process has also led to some tensions between university and school-based staff. The tensions are not solely about criteria for accepting a trainee. A University partnership manager stated:

.. there were two elements that came in at the same time; there was this drive towards School Direct and there was also the ability of trainees to apply for three providers simultaneously, which has trebled the workload straight off by actually having to, in effect, interview three to get one, in the past we've interviewed one to get one (Struthers, 2016).

Recruitment is now driven by this 'supply and demand' model, which may work for schools' yearly needs, but not for universities. A University Head of Teacher Education recounted how a teacher friend had told him:

.if my Principal turned around tomorrow and said we weren't going to run School

Direct any more, I would leap for joy. You know, the challenges of recruitment, of 
interviewing, of recruiting effectively, of organising the training package, etc., or finding the placements.

He then reported that for her:

..the additional challenge now for schools, in her case, is finding schools willing to take on School Direct trainees, but actually with a significant cut to the amount of funding that's available. All of that stuff is driving her to distraction (Struthers, 2016).

From the trainee's point of view, merely meeting a staffing shortage, does not ensure a quality induction for teaching. For example, at one London university, a Secondary PGCE course would have previously offered a dedicated Music Specialist ITE Programme where sufficient students/trainees numbers ensured a learning community. However, with allocations moving to schools, such specialist departments are losing staff. So for a subject like music, it is now usual that on a School Direct route led by a non-university provider, trainees are frequently on their own in the school's music department. In this situation, subject specific mentoring is not likely to be available, nor opportunities to observe other music teachers. Thus a school based route is less likely to offer full subject specialist support; the trainee being in a mixed subject group. Therefore, the calibre of the teacher training programme for such a trainee is totally dependent on local opportunities within the Teaching School Alliance or SCITT.

From the staffing perspective, the once thriving music department in the university may now only have one staff member left, as a reduced governmental allocation/quota the year before meant the department was less viable. For the teacher educator, the previous working context as a collaborative team member offering professional support, dialogue and the space to develop complimentary specialisms to offer trainees, has gone. 


\section{Quality assurance for whom - Ofsted or the profession?}

In the UK government's 2011 legislation, Ofsted was to "monitor the strength of university-school partnerships" (DfE, 2011b, p. 13), requiring university ITE providers to involve schools fully in their provision. So while the balance of power and provision was to shift to schools, who by the same token were expected to work with a provider, it was actually only the university's allocations that would be at risk if the quality of provision within the partnership was not outstanding. This anomaly also binds schools and universities into a 'partnership' motivated by different pressures and needs. As indicated elsewhere, the quality pedagogical partnerships from previous decades in UK, now risk being overtaken by managerial partnerships that merely meet teacher supply demands.

\section{Conclusion:}

What has become evident is that central government understands the significance of schooluniversity partnerships in Teacher Education, but not the complexities. The challenge for those working in ITE partnerships is to manage the bureaucratic demands and power-plays of this neo-liberal environment.

This chapter has demonstrated how present contexts mitigate against flourishing teacher education relationships, built with 'trust', 'respect' and 'professional integrity', exposing instead perfunctory partnerships that ensure economic rather than educative needs are met.

Now the challenge is for all ITE providers to balance across the many different routes into teaching - like the roman rider, without compromising the core knowledge-base, or losing sight of the integrity of the profession.

Alexander, R. J., Craft, M., \& Lynch, J. (1984). Change in teacher education: Context and provision since Robbins. London: Holt, Rhinehart and Winston. 
Allen, J. M., \& Wright, S. E. (2014). Integrating theory and practice in the pre-service teacher education practicum. Teachers and Teaching, 20(2), 136-151.

ATL. (2013). Select Committe Inquiry on School Direct and College of Teaching. Retrieved from https://www.atl.org.uk/Images/atl-response-select-committee-school-direct.pdf

ATL. (2014). 'Learning Lessons' Report (pp. 10): Association of Teachers and Lecturers.

Ball, S. (1994). Education Reform: A Critical and Post-structural Approach. Buckingham: Open University Press.

Beauchamp, G., Clarke, L., Hulme, M., \& Kennedy, A. (2015). Teacher Education in Times of Change: Policy Press.

Beauchamp, G., Clarke, L., Hulme, M., \& Murray, J. (2013). Policy and practice within the United Kingdom. The BERA-RSA Inquiry.

Beck, J. (1999). Makeover or takeover? The strange death of educational autonomy in neoliberal England. British journal of sociology of education, 20(2), 223-238.

Boyd, P., \& Harris, K. (2010). Becoming a university lecturer in teacher education: Expert school teachers reconstructing their pedagogy and identity. Professional Development in Education, 36(1-2), 9-24.

Boyd, P., \& Tibke, J. (2012). Being a school-based teacher educator: developing pedagogy and identity in facilitating work-based higher education in a professional field. Practitioner Research in Higher Education, 6(2), 41-57.

Brown, T., Rowley, H., \& Smith, K. (2016). The beginnings of school led teacher training: New challenges for university teacher education. Retrieved from http://www.esri.mmu.ac.uk/resgroups/schooldirect.pdf:

Campbell, J., \& Husbands, C. (2000). On the Reliability of OFSTED Inspection of Initial Teacher Training: A case study. British Educational Research Journal, 26(1), 39-48. doi:10.1080/014119200109507

Carter, A. (2015). Carter review of intitial teacher training. London Retrieved from https://www.gov.uk/government/uploads/system/uploads/attachment_data/file/399957 /Carter_Review.pdf.

Cochran-Smith, M. (2005). The new teacher education: For better or for worse? Educational Researcher, 34(7), 3-17.

Connell, R. (2009). Good teachers on dangerous ground: Towards a new view of teacher quality and professionalism. Critical studies in education, 50(3), 213-229.

Day, C. (2003). School Reform and transitions in teacher professionalism and identity. International Journal of Educational Research, 37, 677-692.

DES. (1983). The White Paper: Teaching Quality. London: HMSO.

DES. (1984). Initial Teacher Training: Approval of Courses, Circular 3/84. London: HMSO.

DfE. (1992). Initial Teacher Training (Secondary Phase), Circular 9/92. London: DfE.

DfE. (1993). The Government's Proposals for the Reform of Initial Teacher Training. LondonDfE.

DfE. (1993a). The Initial Training of Primary School Teachers: New criteria for Courses (Circular 14/93). London: HMSO.

DfE. (2010). The schools white paper: The importance of teaching: An implementation plan, November 2011. London: Department of Education.

DfE. (2011b). Training our next generation of outstanding teachers. An implementation plan, November 2011. London: DfE.

Edwards, A., \& Mutton, T. (2007). Looking forward: rethinking professional learning through partnership arrangements in Initial Teacher Education. Oxford Review of Education, 33(4), 503-519. 
Ellis, V., Glackin, M., Heighes, D., Norman, M., Nicol, S., Norris, K., . . McNicholl, J. (2013). A difficult realisation: the proletarianisation of higher education-based teacher educators. Journal of Education for Teaching, 39(3), 266-280.

Ellis, V., \& McNicholl, J. (2015). Transforming teacher education: Reconfiguring the academic work: Bloomsbury Publishing.

Evans, A., Holland, M., Wolstenholme, C., Willis, B., \& Hawksley, F. (2006). The role of the Initial Teacher Training Coordinator in the school based element of partnership: to what extent does the Co-ordinator undertake supervision of aspects of quality assurance?

Feiman-Nemser, S. (2001). From preparation to practice: Designing a continuum to strengthen and sustain teaching. The Teachers College Record, 103(6), 1013-1055.

Furlong, J. (2013). Globalisation, neoliberalism, and the reform of teacher education in England. Paper presented at the The educational forum.

Furlong, J., Barton, L., Miles, S., Whiting, C., \& Whitty, G. (2000). Teacher Education in Transition: Re-forming professionalism? Buckingham: Open University Press.

Furlong, J., McNamara, D., Campbell, A., Howson, A., \& Lewis, S. (2008). Partnership, policy and politics: initial teacher education in England under New Labour. Teachers and Teaching: theory and practice, 14(4), 307-318.

Gove, M. (2010). Speech given to National College's Annual Conference in Birmingham. November 25th 2010 This speech was published under the 2010 to 2015 Conservative and Liberal Democrat coalition government: UK Government Retrieved from https://www.gov.uk/government/speeches/michael-gove-to-the-national-collegeannual-conference-birmingham.

Hargreaves, D. H. (2011). Leading a self-improving school system.

Husbands, C. (2015). What are teaching schools for? Management in Education, 29(1), 3134.

Jackson, A., Ashworth, M. (2013). Embedding a University teacher education programme in a school; an evaluation of a school and university partnership. Research Paper University of Cumbria. Retrieved from http://insight.cumbria.ac.uk/1536/

Lincoln, Y. S., \& Guba, E. G. (1985). Naturalistic Inquiry. Beverly Hills CA: Sage.

Lyons, N., \& LaBoskey, V. K. (2002). Narrative inquiry in practice advancing the knowledge of teaching. New York Teachers College Press.

Mahony, P., \& Hextall, I. (2000). Restructuring Teaching: Standards, performance and accountability. London: Routledge.

Mattsson, M., Eilertsen, T. V., \& Rorrison, D. (2012). A practicum turn in teacher education (Vol. 6): Springer Science \& Business Media.

McDonald, M., Kazemi, E., \& Kavanagh, S. S. (2013). Core practices and pedagogies of teacher education a call for a common language and collective activity. Journal of Teacher Education, 64(5), 378-386.

McNamara, D. (1992). The Reform of Teacher Education in England and Wales: Teacher competence, panacea or rhetoric. Journal of Education for Teaching, 18(3), 273-285.

McNamara, O., \& Murray, J. (2013). 4. The School Direct programme and its implications for research-informed teacher education and teacher educators. In L. Florian \& N. Pantić (Eds.), Learning to teach (pp. 14). York: The Higher Education Academy (HEA).

McNamara, O., Murray, J., \& Jones, J. (2014). Workplace Learning in Teacher Education: International Practice and Policy (Vol. 10): Springer Netherlands.

Menter, I., Hulme, M., Elliott, D., \& Lewin, J. (2010). Literature review on teacher education in the 21st century: Scottish Government, Social Research. 
Mentor, I. (2016). Another fine mess! The allocation of initial teacher training places for 2016 (BERA BLOG - Research Matters) Retrieved at:

https://www.bera.ac.uk/blog/another-fine-mess-the-allocation-of-initial-teachertraining-places-for-2016BERA

Mitchell, D., \& Lambert, D. (2015). Subject knowledge and teacher preparation in English secondary schools: the case of geography. Teacher Development, 19(3), 365-380.

Moore, A. (2004). The good teacher: Dominant discourses in teaching and teacher education: Psychology Press.

Struthers, d. (2013). (Disturbing) new school-university partnerships. In L. Beckett (Ed.), Teacher Education Through Active Engagement; Raising the professional voice. London: Routledge.

Struthers, d. (2016). Exploring the impact of multiple preparation routes into teaching in England. (in preparation for BERA 2016). APTE (Association for Partnership in Teacher Education)

Thomson, P. (2000). The Sorcery of Apprenticeships and New/Old Brooms: Thinking about theory, practice, the practicum and change. Teaching Education, 11(1), 67-74.

White, E., Dickerson, C., \& Weston, K. (2015). Developing an appreciation of what it means to be a school-based teacher educator. European Journal of Teacher Education, 38(4), 445-459.

Whitty, G. (2014). Recent developments in teacher training and their consequences for the 'University Project' in education. Oxford Review of Education, 40(4), 466-481.

Wilkin, M., \& Sankey, D. (eds). (1994). Collaboration and transition in Initial Teacher Training. London: Kogan Page.

Zeichner, K., \& Bier, M. (2013). The turn toward practice and clinical experiences in US teacher education. Beitrage Zur Lehrerbildung/Swiss Journal of Teacher Education, 30(2), 153-170. 